Kon, S. K. (I928). Biochem. F. 22, 26 I.

Macrae, T. F., El-Sadr, M. M. \& Sellers, K. C. (1942). Biochem. F. 36, 460.

Majoor, C. L. H. (1946). Yale ₹. biol. Med. 18, 419.

Majoor, C. L. H. (1947). Y. biol. Chem. 169, 583 .

Mitchell, H. H., Beadles, J. R. \& Kruger, J. H. (1927). F. biol. Chem. 73, 767.

Morris, S. \& Wright, N. C. (1935). F. Dairy Res. 6, 289.

Swanson, E. W. \& Herman, H. A. (I943). Res. Bull. Mo. agric. Exp. Sta. no. 372.

Wiese, A. C., Johnson, B. C., Mitchell, H. H. \& Nevens, W. B. (I947). F. Dairy Sci. 30, 87.

Zuntz, N. (1891). Pflig. Arch. ges. Physiol. 49, 483.

\title{
Observations on the Vitamin Metabolism of the Common Fowl
}

\section{The Partition of Free and Combined Riboflavin in the Tissues of the Laying Hen}

\author{
By W. BOLTON \\ Poultry Research Centre, West Mains Road, Edinburgh 9
}

(Received 9 April 195I)

A considerable amount of work has been carried out on the estimation of the minimal requirements for riboflavin by laying hens, both for egg production and for hatchability, but comparatively little is known of the part of riboflavin in egg production.

Common \& Bolton (1946) and Common, Rutledge \& Bolton (1947) showed that the riboflavin content of the blood serum of immature pullets receiving injections of oestrogens increased to between ten and twenty times the pre-treatment value. In the latter paper they demonstrated that differences of the same order existed between serums of normal laying and non-laying hens.

Hertz, Dhyse \& Tullner (1949) confirmed for plasma the increase in riboflavin following oestrogen treatment, and showed that this increase was greater when the diet contained adequate riboflavin than when a diet poor in ribollavin was given.

It has also been shown that the increase in serum riboflavin evoked by oestrogen treatment consists entirely of an increase in the free vitamin, the two naturally occurring combined forms, flavin-mononucleotide (FMN) and flavin-adeninedinucleotide (FAD) being unaffected (Bolton, 1950). Examination of the blood serums of laying hens and of the albumen and yolk of their eggs showed that almost all the riboflavin in the blood serum was in the free form and that $85 \%$ of the riboflavin in the egg was also present as the free vitamin in both albumen and yolk (Bolton, 195I).

It therefore became of interest to ascertain the partition of riboflavin in the oviduct, since this organ forms the link between the blood-stream and the egg. This paper sets out the results obtained from an investigation of the partition in two parts of the oviduct, the magnum, where the yolk of the egg receives its layers of albumen, and the shell gland. Three other tissues were also examined: liver, kidney and heart. Liver and kidney are known to be rich in the vitamin, and from previous work (Bolton, 1947) the concentration in all three is known to reflect the level of intake by young 
chicks. A similar observation has been made for the livers of immature pullets (Hertz et al. 1949). The yolk of the egg is formed in the ovary and takes several days to grow to its full size; this part of the egg has therefore been disregarded in the present study.

\section{EXPERIMENTAL}

Birds. Eleven Brown Leghorn hens bred at this Centre were used. The birds were housed separately in wire cages and were offered $90 \mathrm{~g}$ daily of an all-mash diet. It was suspected that the differences to be measured might be relatively small. A diet low in riboflavin was therefore used to render the differences more easily detectable. The all-mash diet was made up as follows, in parts by weight: maize meal 37 , Sussex-ground oats 38 , wheat offal 10 , fish meal 4 , decorticated extracted groundnut meal 6, cod-liver oil 1 , ground limestone 3.5 and salt 0.5 . To each roo $1 \mathrm{~b}$. of mash $20 \mathrm{~g}$ manganese sulphate were added. Water was supplied ad lib., but no grit was given. The birds consumed all but a few $g$ of the mash each day; when offered Ioo g/day they did not consume any more, and the mash allowance may therefore be taken as ad lib. feeding. Each meal was assayed separately for riboflavin by the method of Kodicek \& Wang (1949). The riboflavin content of the final diet as computed from these assays was $\mathrm{r} \cdot 3 \mu \mathrm{g} / \mathrm{g}$ food; this concentration was found by Norris, Wilgus, Ringrose, Heiman \& Heuser (1936) to represent the minimal requirement for egg production.

Methods. The course of depletion was followed by determining the riboflavin content of the albumen and yolk of the eggs laid. These contents decreased in the course of a month from 90 and 80 to 55 and $40 \mu$ g riboflavin per egg, respectively, but did not fall below these last two values, thereby indicating that depletion was complete.

All hens received the low-riboflavin diet for at least a month. Each hen was weighed, killed and then bled to remove as much blood from the tissues as possible. The stage in the ovulatory cycle was assessed as accurately as possible by visual examination during dissection, and the five tissues were removed, weighed and stored in the refrigerator overnight to become thoroughly cold.

The partition of riboflavin into the free vitamin, FMN and FAD was carried out by a macromodification of the method of Bessey, Lowry \& Love (I949), since the microfluorimeter necessary for the original method was not available. A portion of $5 \mathrm{~g}$ of tissue was taken for the initial maceration and all analyses were completed within $48 \mathrm{~h}$ of the death of the bird.

\section{RESULTS}

Table I contains the body-weight and lengths of magnum and shell gland for each hen. Table 2 gives the mean content of the three riboflavin fractions of the five tissues examined in each hen in terms of $\mu \mathrm{g}$ total content and of concentration/g tissue.

\section{DISCUSSION}

Liver, kidney and heart. All the hens had received the low-riboflavin diet for at least a month, and depletion of the bird, as indicated by the content of riboflavin in the egg, was as complete as the diet permitted, yet riboflavin was present as the free 
vitamin in all the tissues. This suggests that a metabolic demand for the vitamin in the unphosphorylated form exists in the body, a view substantiated by the similar results of Bessey et al. (I949) on the tissues from rats given a low-riboflavin diet.

Table I. Body-weight and lengths of magnum and shell gland for each hen

\begin{tabular}{|c|c|c|c|c|}
\hline \multirow[b]{2}{*}{ Hen no. } & \multicolumn{3}{|c|}{ Length of } & \multirow[b]{2}{*}{ Stage of ovulatory cycle } \\
\hline & $\begin{array}{c}\text { Body-weight } \\
\text { (g) }\end{array}$ & $\begin{array}{c}\text { Magnum } \\
(\mathrm{mm})\end{array}$ & $\begin{array}{l}\text { Shell gland } \\
\text { (mm) }\end{array}$ & \\
\hline L. 3113 & 1617 & 306 & 38 & Nearing ovulation \\
\hline L. 3103 & 1530 & 306 & 46 & Nearing ovulation \\
\hline L. 3004 & 2040 & 299 & $5 \mathrm{I}$ & Nearing ovulation \\
\hline L. 3012 & 1628 & 241 & 63 & Egg just into shell gland \\
\hline L. 3 IOI & 1324 & 299 & 53 & Egg just into shell gland \\
\hline L. 3001 & I 777 & 264 & 51 & Egg just into shell gland \\
\hline L. 3035 & 1512 & 234 & 48 & Fully formed egg in shell gland \\
\hline L. 3096 & 1578 & 216 & 84 & Fully formed egg in shell gland \\
\hline L. 3021 & I 855 & 267 & 59 & Ovum atretic \\
\hline L. 3109 & 1585 & 259 & 61 & Ovum just into magnum \\
\hline L. 3094 & 1480 & 221 & 38 & Going out of lay \\
\hline
\end{tabular}

Table 2. Mean total riboflavin contents of the tissues of the hens

\begin{tabular}{|c|c|c|c|c|c|c|c|c|}
\hline \multirow[b]{2}{*}{ Tissue } & \multicolumn{2}{|c|}{ Free riboflavin* } & \multicolumn{2}{|c|}{$\begin{array}{c}\text { Flavin- } \\
\text { mononucleotide* }\end{array}$} & \multicolumn{2}{|c|}{$\begin{array}{l}\text { Flavin-adenine- } \\
\text { dinucleotide* }\end{array}$} & \multicolumn{2}{|c|}{ Total* } \\
\hline & $(\mu g)$ & $(\mu \mathrm{g} / \mathrm{g})$ & $(\mu \mathrm{g})$ & $(\mu \mathrm{g} / \mathrm{g})$ & $(\mu \mathrm{g})$ & $(\mu g / g)$ & $(\mu \mathrm{g})$ & $(\mu \mathrm{g} / \mathrm{g})$ \\
\hline $\begin{array}{l}\text { Liver } \\
\text { Kidney } \\
\text { Heart } \\
\text { Magnum } \\
\text { Shell gland }\end{array}$ & $\begin{array}{r}39 \pm 5 \\
9 \pm 2 \\
3 \pm 1 \\
43 \pm 9 \\
6 \pm 1\end{array}$ & $\begin{array}{l}1.2 \pm 0.2 \\
0.9 \pm 0.2 \\
0.6 \pm 0.1 \\
2.0 \pm 0.3 \\
0.39 \pm 0.07\end{array}$ & $\begin{array}{r}45 \pm 6 \\
20 \pm 4 \\
6 \pm 1 \\
28 \pm 5 \\
6 \pm 1\end{array}$ & $\begin{array}{l}I \cdot 3 \pm 0.2 \\
I \cdot 6 \pm 0.3 \\
I \cdot 2 \pm 0.2 \\
I \cdot 4 \pm 0.2 \\
0.37 \pm 0.04\end{array}$ & $\begin{array}{r}581 \pm 36 \\
200 \pm 17 \\
56 \pm 7 \\
69 \pm 7 \\
39 \pm 1\end{array}$ & $\begin{array}{r}17 \cdot 2 \pm 1 \cdot 0 \\
17 \cdot 0 \pm 1 \cdot 1 \\
10 \cdot 2 \pm 0.9 \\
3.4 \pm 0.2 \\
2.6 \pm 0.2\end{array}$ & $\begin{array}{r}665 \pm 41 \\
229 \pm 19 \\
65 \pm 8 \\
140 \pm 6 \\
49 \pm 6\end{array}$ & $\begin{array}{r}19.7 \pm 1.0 \\
19.5 \pm 1.1 \\
12.0 \pm 1.0 \\
7.0 \pm 0.5 \\
3.3 \pm 0.2\end{array}$ \\
\hline
\end{tabular}

The amounts of free riboflavin present in the kidney and heart are so small that they can contribute little to the demand for the free vitamin as the albumen is laid down. On the other hand, the liver contains substantial stores of free riboflavin and cannot be so disregarded. When the results are expressed on a percentage basis, it is seen that the partitions of the riboflavin into free vitamin, FMN and FAD are almost identical in each of the three tissues. Moreover, when the contents are considered according to the stage in the ovulatory cycle, a relationship is not observed, although the number of results is insufficient to rule out the liver on this count alone.

However, when all the information is taken together, it suggests that, though the riboflavin contents of liver, kidney and heart reflect the level of intake and to that extent may serve as an ultimate reserve for egg production, these tissues are not involved in the day-to-day metabolism of riboflavin in egg formation.

Magnum and shell gland. In the process of egg formation, the ovum spends about $3 \mathrm{~h}$ in the magnum and $20 \mathrm{~h}$ in the shell gland. The albumen is secreted during the passage of the ovum through the magnum, and Conrad \& Scott (1942) have shown that albumen accumulates in this tissue during the intervals between the passage of eggs. 
It is therefore of interest to find that the magnum contains the largest amount of free riboflavin, whether this is expressed as $\mu \mathrm{g} / \mathrm{g}$ tissue or as total amount in the tissue.

It has been mentioned above that the albumen of each egg from the depleted hens contained $55 \mu \mathrm{g}$ riboflavin. Of this about $44 \mu \mathrm{g}$ were present as the free vitamin. The results have therefore been examined to see whether, in fact, the amounts found in the magnum alone were sufficient to permit this secretion of $44 \mu \mathrm{g}$. The results are set out in 'Table 3; those for hen no. L. 302I are given along with those for the two birds that had fully formed eggs in the shell glands, since she had laid within a few hours of her death.

\section{Table 3. Free riboflavin in the magnum of the laying hen} at different stages of the ovulatory cycle

Condition of hen

Nearing ovulation (hens nos. L. 3 II 3, L. 3103 and L. 3004)

Egg just into shell gland (hens nos. L. 3012 , L. 3 ror and L. $300 \mathrm{r}$ )

Egg in shell gland, fully formed (hens nos. L. 302 r, L. 3035 and L. 3096)

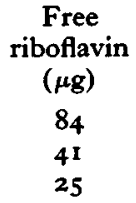

The difference in content of free riboflavin between those birds about to ovulate and those with an egg just passed into the shell gland amounts to $43 \mu \mathrm{g}$, which corresponds to the amount of free riboflavin in the egg.

The percentage composition of the shell gland suggests that this tissue may also be involved in riboflavin secretion, but the total amount present is so small that it would play a minor part compared with the magnum. An examination of the results failed to reveal any differences related to the stage in the ovulatory cycle, and it is concluded that this part of the oviduct plays a negligible, if any, part in the secretion of riboflavin into the egg.

Though the total number of birds examined was not enough securely to establish the premise, the results obtained suggest that the magnum is the only investigated tissue involved in the day-to-day mechanism affecting the amount of riboflavin in the egg. Immediately before ovulation the content of free riboflavin is high; after the egg has passed through the organ the content is reduced by an amount equal to the content of free vitamin in the egg. It is therefore suggested that the riboflavin in the albumen is secreted at the same time as the albumen layer itself and probably passes to the egg with the albumen.

\section{SUMMARY}

I. The partition of riboflavin into free vitamin, flavin-mononucleotide and flavinadenine-dinucleotide in the liver, kidney, heart, magnum and shell gland of laying hens has been determined.

2. In liver, kidney and heart, about $85 \%$ of the vitamin is present as the dinucleotide, with slightly more mononucleotide than free riboflavin accounting for the rest.

3. In the magnum there is $50 \%$ more free riboflavin than mononucleotide and three times as much dinucleotide as mononucleotide. 
4. The shell gland has three-quarters of its riboflavin present as dinucleotide, the rest being equally divided between the free form and the mononucleotide.

5. It is suggested that the magnum is the tissue involved in the day-to-day mechanism affecting the amount of riboflavin in the egg.

The author thanks Dr A. W. Greenwood, the Director of this Centre, for his advice and criticism, and Miss D. R. Mitchell for assistance both in the care of the birds and in the analyses.

\title{
REFERENCES
}

Bessey, O. A., Lowry, O. H. \& Love, R. H. (1949). F. biol. Chem. 180, 755.

Bolton, W. (1947). F. agric. Sci. 37, 316.

Bolton, W. (1950). Nature, Lond., 166, 912.

Bolton, W. (I95I). World's Poult. Congr. Ix, Paris, 2, 27.

Common, R. H. \& Bolton, W. (1946). Nature, Lond., 158, 95.

Common, R. H., Rutledge, W. A. \& Bolton, W. (1947). F. Endocrinol. 5, 12 I.

Conrad, R. M. \& Scott, H. M. (1942). Poult. Sci. 2r, 8 r.

Hertz, R., Dhyse, F. G. \& Tullner, W. W. (1949). Endocrinology, 44, 283.

Kodicek, E. \& Wang, Y. L. (1949). Biochem. F. 44, 340.

Norris, L. C., Wilgus, H. S. Jr., Ringrose, A. T., Heiman, V. \& Heuser, G. F. (1936). Bull. Cornell agric. Exp. Sta. no. 660 .

\section{The Use of Chicks for the Biological Assay of Members of the Vitamin B Complex}

\section{Tests on Natural Materials and Comparison with Microbiological and Other Assays}

\author{
BY M. E. COATES, J. E. FORD, G. F. HARRISON, S. K. KON, \\ E. E. SHEPHEARD AND F. W. WILBY \\ National Institute for Research in Dairying, University of Reading
}

(Received 21 Fune 195 I)

In a previous paper Coates, Kon \& Shepheard (1950) suggested methods for the biological assay of nicotinic acid, riboflavin, pyridoxin, pantothenic acid and folic acid with chicks. The accuracy of the methods was determined for preparations of the pure vitamins. The present paper reports their application to assaying the same vitamins in various natural materials, and the results are compared with those found by microbiological or other means.

\section{EXPERIMENTAL}

\section{Substances tested}

While the technique of the chick assays for the B-vitamins was still in the experimental stage, the materials chosen for study were those, such as milk and yeast products, already well studied by other methods. However, the chick tests were primarily designed for comparison with results obtained by microbiological techniques, 